\title{
Production, Purification, and Characterization of Polygalacturonase from Mucor circinelloides ITCC 6025
}

\author{
Akhilesh Thakur, Roma Pahwa, Smarika Singh, and Reena Gupta \\ Deparment of Biotechnology, Himachal Pradesh University, Summer Hill, Shimla 171005, India \\ Correspondence should be addressed to Reena Gupta, reenagupta_2001@yahoo.com
}

Received 9 January 2010; Accepted 30 March 2010

Academic Editor: Roberto Fernandez-Lafuente

Copyright ( $\odot 2010$ Akhilesh Thakur et al. This is an open access article distributed under the Creative Commons Attribution License, which permits unrestricted use, distribution, and reproduction in any medium, provided the original work is properly cited.

\begin{abstract}
Mucor circinelloides produced an extracellular polygalacturonase enzyme, the production of which was enhanced when various production parameters were optimized. Maximum polygalacturonase (PGase) activity was obtained in $48 \mathrm{~h}$ at $30^{\circ} \mathrm{C}$ and $\mathrm{pH} 4.0$ with pectin methyl ester $(1 \% \mathrm{w} / \mathrm{v})$ as carbon source and a combination of casein hydrolysate $(0.1 \% \mathrm{w} / \mathrm{v})$ and yeast extract $(0.1 \%$ $\mathrm{w} / \mathrm{v}$ ) as nitrogen source. The enzyme was purified to homogeneity (13.3-fold) by Sephacryl S-100 gel-filtration chromatography. Its molecular weight was $66 \mathrm{kDa}$ on SDS-PAGE. The enzyme was found to have $K_{m}$ and $V_{\max }$ values of $2.2 \mathrm{mM}$ and $4.81 \mathrm{IU} / \mathrm{ml}$ at $0.1 \%$ to $0.5 \%(\mathrm{w} / \mathrm{v})$ concentration of the substrate. The addition of phenolic acids $(0.05 \mathrm{mM})$, metal ions such as $\mathrm{Mn}^{+2}, \mathrm{Co}^{+2}$, $\mathrm{Mg}^{+2}, \mathrm{Fe}^{+3}, \mathrm{Al}^{+3}, \mathrm{Hg}^{+2}$, and $\mathrm{Cu}^{+2}$, and thiols had inhibitory effect on the enzyme. The enzyme showed maximum activity in the presence of polygalacturonic acid $(0.1 \% \mathrm{w} / \mathrm{v})$ at $\mathrm{pH} 5.5$ and $42^{\circ} \mathrm{C}$.
\end{abstract}

\section{Introduction}

Pectinases hydrolyze pectic substances. They have a share of $25 \%$ in the global sale of the food enzymes. Pectinases are one of the most widely distributed enzymes in bacteria, fungi, and plants [1]. Polygalacturonases (PGases) catalyze the random hydrolysis of 1,4 $\alpha$-D galacturonic acid linkages in smooth region of pectin $[2,3]$. The pectinolytic enzymes degrade the pectic substances found in plant tissues, thereby, having numerous applications in various types of industries such as juice and food industries [4], for example, increase in the yield of fruit juice from pulp, removal of haze from juices to get a clear product [5], paper and pulp industry [6], natural fibres treatment in textile industries [7] such as retting of flax fibres [8], production of Japanese paper [9], and bast fibers [10]. Pectinase production by microbes varies according to the composition of growth medium and the cultivation conditions, that is, $\mathrm{pH}$, temperature, aeration, agitation, and incubation time [11]. Solid state fermentation has been found to be more suitable for pectinase production as compared to the submerged condition [12]. Recently, five pectinolytic enzymes by Aspergillus niger MIUG-16 were purified using a combination of chromatographic techniques [13]. Commercial enzyme preparations used in processing of food, traditionally, comprising of the mixtures of polygalacturonase, pectate lyase, and pectin esterase, are almost exclusively derived from fungal species, especially Mucor and Aspergillus [14]. Biochemical and thermal characterization of crude exo-polygalacturonase produced by Aspergillus sojae has also been reported [15]. Recently, the enzyme polygalacturonase has been targeted to develop nonfungicidal control strategies in order to avoid postharvest losses due to a fungal pathogen [16]. Each application requires unique properties with respect to specificity, stability, temperature, and $\mathrm{pH}$ dependence. The immense potential of polygalacturonase, particularly its application in juice clarification, can be of tremendous importance to Himachal Pradesh as it deals with large amount of horticultural products, especially apples. The apple juice faces the problems of turbidity and suspended particles like pectin, cellulose, and hemicellulose. Due to these factors, the juice fails to match international standards. The quality of juice can be improved by appropriate treatment with pectinolytic enzymes leading to the increased market potential, thereby, providing a significant boost to the economy of hill state. 
Keeping in view the above consideration, in this paper we report production, purification, and characterization of PGase from saprophytic fungus, Mucor circinelloides ITCC 6025.

\section{Materials and Methods}

2.1. Chemicals. All the chemicals used were either procured from Sigma Aldrich (USA) or HIMEDIA (Mumbai, India) and were of high analytical grade. Polygalacturonic acid from citrus fruit (Sigma) was used as substrate. The fungus Mucor circinelloides ITCC 6025 was isolated from soil and identified at the division of plant pathology, IARI, New Delhi.

\subsection{Maintenance of M. circinelloides and Polygalacturonase} Production. The fungal culture was stored on Potato Dextrose Agar (PDA) slants and incubated at $30^{\circ} \mathrm{C}$ for 5 days. The heavily sporulated slants were stored at $4^{\circ} \mathrm{C}$ and subculturing was done after every 45 days. The spores were harvested by adding $2 \mathrm{~mL}$ sterile saline containing $0.01 \%$ Tween 20 to a sporulated slant. About $2 \times 10^{5}$ spores were required for better production of enzyme. $500 \mathrm{~mL}$ of medium consisting of $\mathrm{KCl}(0.05 \%), \mathrm{MgSO}_{4} .7 \mathrm{H}_{2} \mathrm{O}(0.01 \%)$, trisodium citrate dihydrate $(0.1 \%)$, Citric acid anhydrous $(0.1 \%)$, Yeast extract $(0.1 \%)$, Casein hydrolysate $(0.1 \%)$, and Pectin $(1 \%)$ was used for production purpose. The $\mathrm{pH}$ of the medium was adjusted to 4.0 with $0.1 \mathrm{~N} \mathrm{HCl}$. The medium was autoclaved at 15 psi for 20 minutes. $25 \mathrm{~mL}$ of sterile production medium was taken in $250 \mathrm{~mL}$ conical flasks, or $50 \mathrm{~mL}$ of sterile production medium was taken in $500 \mathrm{~mL}$ conical flasks for better growth and production. About $2 \times 10^{5}$ spores were inoculated in each $250 \mathrm{~mL}$ conical flask and the flasks were incubated in an ORBITEK rotary shaker at $30^{\circ} \mathrm{C}$ at $150 \mathrm{rpm}$. After 48 hours, the culture was harvested and filtered through Whatmann no. 1 filter paper. The filtered cell-free broth was used as crude enzyme. The effect of various carbon sources, that is, pectin (methyl ester), apple pectin, glucose, fructose, galactose, and maltose $(1 \% \mathrm{w} / \mathrm{v})$ was studied at $\mathrm{pH} 4.0$ and temperature $30^{\circ} \mathrm{C}$. Each of various nitrogen sources ammonium sulphate, ammonium nitrate, ammonium chloride, ammonium dihydrogen phosphate, casein hydrolysate, and yeast extract was individually added to production broth at a concentration of $0.1 \%(\mathrm{w} / \mathrm{v})$.

2.3. Enzyme Assay. The PGase activity was assayed by estimating the amount of reducing sugar released under assay conditions. The reducing sugar was quantified by the method of Somogyi [17]. The substrate used for assay was 0.5\% PGA (polygalacturonic acid), that is, $0.5 \mathrm{~g}$ of PGA in $100 \mathrm{~mL}$ of $0.05 \mathrm{M}$ citric acid-sodium citrate buffer, $\mathrm{pH}$ 5.4. The assay mixture consisted of $980 \mu \mathrm{l}$ of freshly prepared substrate and $20 \mu \mathrm{l}$ of enzyme and incubated at $40^{\circ} \mathrm{C}$ for 20 minutes. The reaction was stopped by keeping the reaction mixture in boiling water bath for 3 minutes. To the reaction mixture, $500 \mu \mathrm{l}$ of alkaline copper tartrate reagent was added and tubes were again kept in boiling water bath for 20 minutes. In the control, $20 \mu \mathrm{l}$ of enzyme was added after adding alkaline copper tartrate reagent. The tubes were cooled and
$500 \mu \mathrm{l}$ of arsenomolybdate reagent was added and thoroughly mixed. The absorbance was recorded at $620 \mathrm{~nm}$ (using Perkin Elmer model Lambda 12 UV/VIS spectrometer) against a blank consisting of $1 \mathrm{~mL}$ citrate buffer, $500 \mu \mathrm{l}$ alkaline copper tartrate reagent, and $500 \mu \mathrm{l}$ arsenomolybdate reagent. The amount of galacturonic acid released per $\mathrm{mL}$ per minute was calculated from standard curve of galacturonic acid. One Unit of PGase activity was defined as the amount of enzyme required to release one micromole of galacturonic acid per $\mathrm{mL}$ per minute under standard assay conditions.

2.4. Determination of Protein Concentration. The protein concentration was determined using BSA as standard by the method of Lowry et al. [18].

\subsection{Purification by Gel-Filtration (Sephacryl S-100) Chro-} matography. PGase was purified to homogeneity by chilled ethanol $(60 \%)$ precipitation and column chromatography. The partial purification of enzyme was done by adding chilled ethanol (60\%) to crude enzyme and keeping it for overnight incubation. The precipitates thus obtained were spun at $15000 \mathrm{rpm}$ for 15 minutes at $4^{\circ} \mathrm{C}$. The pellet obtained was dissolved in minimum volume of assay buffer (sodium-citrate buffer), $\mathrm{pH}$ 5.4. It was again centrifuged at $25000 \mathrm{rpm}$ for 20 minutes at $4^{\circ} \mathrm{C}$ to obtain a viscous sample. The precipitated enzyme was filtered through $0.22 \mu$ filter, and $2 \mathrm{~mL}$ of this filtered precipitated enzyme was loaded on gel-permeation column Sephacryl S-100 (bed volume $120 \mathrm{~mL}$ ). All the eluted fractions were estimated for enzyme activity and absorbance at $280 \mathrm{~nm}$. The fractions showing the highest PGase activity were pooled and assayed for protein content. The specific activity of purified enzyme fractions was compared to that of crude enzyme and fold purification was calculated. Purified enzyme was lyophilized by Flexi-Dry MP to make it more concentrated for SDS-PAGE.

The relative molecular weight of the purified enzyme was estimated by SDS-PAGE (12\%) according to the method of Laemmli [19]. Proteins were stained with coomassie brilliant blue R-250.

\subsection{Characterization of Polygalacturonase}

2.6.1. Optimization of Temperature and $p H$. The optimum temperature and $\mathrm{pH}$ of the enzyme were determined by measuring the PGase activity at various temperatures $(36,38$, $40,42,44$, and $\left.46^{\circ} \mathrm{C}\right)$ at $\mathrm{pH} 5.4$ and $\mathrm{pH}(4.0,4.5,5.0,5.5,6.0$, and 6.5) at $42^{\circ} \mathrm{C}$ using $50 \mathrm{mM}$ citrate buffer with PGA (0.5\%) as substrate.

2.6.2. Optimization of Incubation Time. Optimum reaction time was determined by incubating the reactants for different time intervals $(5,10,15,20,25$, and 30 minutes) and performing the assay for PGase activity at optimized temperature and $\mathrm{pH}$.

2.6.3. pH Stability of Enzyme. To determine the $\mathrm{pH}$ stability, the enzyme was preincubated in $0.05 \mathrm{mM}$ sodium-citrate 
TABLE 1: Effect of various carbon sources on PGase production from Mucor circinelloides.

\begin{tabular}{lcc}
\hline $\begin{array}{l}\text { Carbon source } \\
1 \%(\mathrm{w} / \mathrm{v})\end{array}$ & $\begin{array}{c}\text { Enzyme activity } \\
\left(\mu \mathrm{mol} \mathrm{mL} \mathrm{min}^{-1}\right)\end{array}$ & $\begin{array}{c}\text { Relative Activity } \\
(\%)\end{array}$ \\
\hline Pectin (methyl ester) & 9.15 & 100.00 \\
Apple pectin & 8.41 & 91.91 \\
Glucose & 2.12 & 23.16 \\
Fructose & 5.86 & 64.04 \\
Galactose & 2.30 & 25.13 \\
Maltose & 2.50 & 27.32 \\
\hline
\end{tabular}

The experiment was carried out using casein hydrolysate as nitrogen source.

TABle 2: Effect of various nitrogen sources on PGase production from Mucor circinelloides.

\begin{tabular}{lcc}
\hline $\begin{array}{l}\text { Nitrogen source } \\
0.1 \%(\mathrm{w} / \mathrm{v})\end{array}$ & $\begin{array}{c}\text { Enzyme activity } \\
\left(\mu \mathrm{mol} \mathrm{mL}^{-1} \mathrm{~min}^{-1}\right)\end{array}$ & $\begin{array}{c}\text { Relative Activity } \\
(\%)\end{array}$ \\
\hline$\left(\mathrm{NH}_{4}\right)_{2} \mathrm{SO}_{4}$ & 4.56 & 45.64 \\
$\left(\mathrm{NH}_{4}\right) \mathrm{NO}_{3}$ & 5.43 & 55.35 \\
$\mathrm{NH}_{4} \mathrm{Cl}$ & 6.25 & 62.56 \\
$\left(\mathrm{NH}_{4}\right)_{2} \mathrm{SO}_{4} \mathrm{FeSO}_{4}$ & 2.12 & 21.22 \\
$\left(\mathrm{NH}_{4}\right) \mathrm{H}_{2} \mathrm{PO}_{4}$ & 3.16 & 31.63 \\
$\mathrm{CH}$ & 8.55 & 85.58 \\
$\mathrm{YE}$ & 9.55 & 99.59 \\
$\mathrm{CH}+\mathrm{YE}(\mathrm{Control})$ & 9.99 & 100.00 \\
\hline
\end{tabular}

The experiment was carried out using pectin methyl ester as carbon source.

buffer ( $\mathrm{pH} 3.5-7.0$ ) for 4 hours at $42^{\circ} \mathrm{C}$ and the enzyme activity was assayed under standard assay conditions.

2.6.4. Thermostability of Enzyme. To determine the halflife of enzyme, the enzyme was incubated at $42^{\circ} \mathrm{C}$ and the enzyme activity was determined upto 7 hours after every 1 hour. For determination of thermostability, the enzyme was incubated at $50^{\circ} \mathrm{C}$ for 5 hours and the enzyme activity was determined after every 30 minutes.

2.6.5. Effect of Metal Ions. The assay was performed in the presence of various metal ions at a final concentration of $1 \mathrm{mM}$ in $50 \mathrm{mM}$ sodium-citrate buffer $\mathrm{pH}$ 5.4.

2.6.6. Substrate Specificity. A study of substrate specificity for polygalacturonase from $M$. circinelloides was made by using polygalacturonic acid, pectin citrus (DE-89\%), pectin apple (methyl 7.8\%), potato dextrose agar, and amylopectin $(0.1 \%$ each).

2.6.7. Determination of $K_{m}$ and $V_{\max }$ Value. $K_{m}$ and $V_{\max }$ values of the enzyme were determined by measuring the reaction velocity at different concentrations of the substrate (PGA) $0.1 \%$ to $0.5 \%(\mathrm{w} / \mathrm{v})$. The reciprocal of the reaction velocity $(1 / \mathrm{V})$ was plotted against the reciprocal of the substrate concentration (1/[S]) to determine the $K_{m}$ and $V_{\max }$ values by the Line-Weaver-Burke plot.
2.6.8. Effect of Thiols and Reducing Agents. A study of different thiols was performed by preincubating the enzyme $(0.3 \mathrm{~mL})$ for 5 minutes at $37^{\circ} \mathrm{C}$ before starting the reaction with PGA making the final concentration of thiols to $1 \mathrm{mM}$ with $0.05 \mathrm{M}$ citrate buffer, $\mathrm{pH}$ 5.4.

2.6.9. Effect of Phenolics. The assay was performed in the presence of various phenolic acids at a final concentration of $0.05 \mathrm{mM}$ in $50 \mathrm{mM}$ citrate buffer, $\mathrm{pH}$ 5.4, by preincubating the enzyme for 5 minutes at $37^{\circ} \mathrm{C}$ before starting the reaction with PGA.

\section{Results and Discussion}

3.1. Polygalacturonase (PGase) Production by M. circinelloides ITCC-6025. Amongst various carbon sources tested for PGase production pectin methyl ester $1 \%(\mathrm{w} / \mathrm{v})$ was the best source followed by apple pectin (Table 1). Earlier, the PGase activity was reported to be maximally supported by pure pectin followed by wheat bran and maximum PGase activity was observed in citrus pectin (Var. mussami) by thermophilic Aspergillus fumigatus [20]. PGase production was enhanced using various sugars and complex agroproducts $1 \%(\mathrm{w} / \mathrm{v})$ [21]. Addition of glucose in culture medium led to decrease in PGase production in Aspergillus niger [22].

Amongst various nitrogen sources tested, the best PGase production was obtained when Casein hydrolysate $(\mathrm{CH})$ $0.1 \%(\mathrm{w} / \mathrm{v})$ and Yeast extract (YE) $0.1 \%(\mathrm{w} / \mathrm{v})$ were used together. YE alone also gave comparable activity. Among the inorganic nitrogen sources, maximum activity was obtained with $\mathrm{NH}_{4} \mathrm{Cl}$ (Table 2). There have been reports of enhanced PGase production when $\mathrm{NH}_{4} \mathrm{Cl}$ was used as nitrogen source [23]. It has been reported that nitrogen limitation decreases the polygalacturonase production [24].

3.2. Enzyme Purification. The enzyme was purified about $13.3-$ fold with a specific activity of $31.74 \mathrm{IU} / \mathrm{mg}$ giving a yield of 3.4\% after Sephacryl S-100 gel-permeation chromatography (Figure 1, Table 3 ) which resulted in almost a single peak when absorbance was recorded at $280 \mathrm{~nm}$. Earlier, various polygalacturonases have been purified using gel-permeation chromatography $[25,26]$.

The purified polygalacturonase showed a single band on $12 \%$ SDS-PAGE (Figure 2). The molecular weight was found to be $66 \mathrm{kDa}$ which indicated that it was novel enzyme from Mucor sp. It was comparable to exoenzymes secreted by some other fungi [27-30].

3.3. Enzyme Characterization. The purified enzyme exhibited optimum polygalacturonase activity at a temperature of $42^{\circ} \mathrm{C}$ (Table 4 ) and $\mathrm{pH}$ of 5.5 (Table 5 ). The maximum activity of polygalacturonase from $M$. circinelloides was obtained using $20 \mu \mathrm{l}$ of enzyme after 20 minutes incubation at $42^{\circ} \mathrm{C}$ and $\mathrm{pH}$ of 5.5 (Table 6). The enzyme was stable within $\mathrm{pH}$ range of 4.5 to 6.5 with optimum $\mathrm{pH}$ of 5.5. A further increase in $\mathrm{pH}$ led to a marked decrease in stability of the enzyme (Table 7). The enzyme was found to have 
TABLe 3: Purification of polygalacturonase produced extracellularly by Mucor circinelloides.

\begin{tabular}{|c|c|c|c|c|c|c|}
\hline Step & Volume (mL) & Total Activity (IU) & Total Protein (mg) & Specific Activity (IU/mg) & Fold Purification & $\%$ Yield \\
\hline Crude & 1000 & 624 & 261 & 2.391 & 1 & 100 \\
\hline Ethanol $(60 \%)$ & 75 & 39.6 & 7.8 & 5.077 & 2.12 & 6.35 \\
\hline Sephacryl S-100 & 42 & 21.33 & 0.672 & 31.74 & 13.3 & 3.4 \\
\hline
\end{tabular}

TABLE 4: Effect of temperature on activity of polygalacturonase from Mucor circinelloides.

\begin{tabular}{lc}
\hline Temperature $\left({ }^{\circ} \mathrm{C}\right)$ & Activity $(\mathrm{IU} / \mathrm{mL})$ \\
\hline 36 & 1.58 \\
38 & 2.32 \\
40 & 2.75 \\
42 & 3.80 \\
44 & 2.40 \\
46 & 1.55 \\
\hline
\end{tabular}

The experiment was carried out at $\mathrm{pH}$ 5.4.

TABLE 5: Effect of $\mathrm{pH}$ on activity of polygalacturonase from Mucor circinelloides.

\begin{tabular}{lc}
\hline $\mathrm{pH}$ & Activity $(\mathrm{IU} / \mathrm{mL})$ \\
\hline 4.0 & 1.55 \\
4.5 & 2.30 \\
5.0 & 2.80 \\
5.5 & 3.62 \\
6.0 & 1.75 \\
6.5 & 1.15 \\
\hline
\end{tabular}

The experiment was carried out at a temperature of $42^{\circ} \mathrm{C}$.

TABLE 6: Effect of reaction time on activity of polygalacturonase from Mucor circinelloides.

\begin{tabular}{lc}
\hline Reaction time (min.) & Activity $(\mathrm{IU} / \mathrm{mL})$ \\
\hline 5 & 1.80 \\
10 & 2.80 \\
15 & 3.45 \\
20 & 3.82 \\
25 & 1.82 \\
30 & 1.10 \\
\hline
\end{tabular}

The experiment was carried out at a temperature of $42^{\circ} \mathrm{C}$ and $\mathrm{pH} 5.5$.

TABLE 7: Effect of $\mathrm{pH}$ on stability of polygalacturonase from Mucor circinelloides.

\begin{tabular}{ccc}
\hline $\mathrm{pH}$ & Enzyme Activity $(\mathrm{IU} / \mathrm{mL})$ & Relative Activity $(\%)$ \\
\hline 3.5 & 1.50 & 41.0 \\
4.0 & 2.30 & 63.0 \\
4.5 & 2.51 & 68.7 \\
5.0 & 3.42 & 93.6 \\
5.5 & 3.65 & 100.0 \\
6.0 & 2.68 & 73.4 \\
6.5 & 2.45 & 67.1 \\
7.0 & 1.30 & 35.6 \\
\hline
\end{tabular}

TABLE 8: Stability of polygalacturonase at $42^{\circ} \mathrm{C}$ from Mucor circinelloides.

\begin{tabular}{lcc}
\hline Time $(\mathrm{h})$ & Enzyme Activity $(\mathrm{IU} / \mathrm{mL})$ & Relative Activity $(\%)$ \\
\hline 0 & 3.5 & 100.0 \\
1 & 3.4 & 97.1 \\
2 & 2.5 & 71.4 \\
3 & 2.1 & 60.0 \\
4 & 1.9 & 54.2 \\
5 & 1.7 & 50.0 \\
6 & 1.6 & 45.7 \\
7 & 1.5 & 42.8 \\
\hline
\end{tabular}

TABLe 9: Stability of polygalacturonase at $50^{\circ} \mathrm{C}$ from Mucor circinelloides.

\begin{tabular}{lcc}
\hline Time $(\mathrm{h})$ & Enzyme Activity $(\mathrm{IU} / \mathrm{mL})$ & Relative Activity $(\%)$ \\
\hline 0.0 & 3.70 & 100.00 \\
0.5 & 3.60 & 97.20 \\
1.0 & 2.70 & 72.90 \\
1.5 & 2.20 & 59.45 \\
2.0 & 1.81 & 50.00 \\
2.5 & 1.65 & 44.50 \\
3.0 & 1.34 & 36.20 \\
3.5 & 1.25 & 33.70 \\
4.0 & 1.10 & 29.70 \\
4.5 & 0.92 & 24.80 \\
5.0 & 0.85 & 22.90 \\
\hline
\end{tabular}

TABLE 10: Effect of metal ions on activity of polygalacturonase from Mucor circinelloides.

\begin{tabular}{lcc}
\hline $\begin{array}{l}\text { Metal ions } \\
(1 \mathrm{mM})\end{array}$ & $\begin{array}{c}\text { Enzyme Activity } \\
(\mathrm{IU} / \mathrm{mL})\end{array}$ & $\begin{array}{c}\text { Relative Activity } \\
(\%)\end{array}$ \\
\hline $\mathrm{Al}^{+3}$ & 3.06 & 80.60 \\
$\mathrm{Fe}^{+2}$ & 2.73 & 72.00 \\
$\mathrm{Hg}^{+2}$ & 1.71 & 45.10 \\
$\mathrm{Mg}^{+2}$ & 3.23 & 85.16 \\
$\mathrm{Mn}^{+2}$ & 3.68 & 96.85 \\
$\mathrm{Zn}^{+2}$ & 2.77 & 72.98 \\
$\mathrm{Co}^{+2}$ & 3.13 & 82.60 \\
$\mathrm{Cu}^{+2}$ & 3.07 & 80.80 \\
$\mathrm{Control}$ & 3.80 & 100.00 \\
\hline
\end{tabular}

The experiment was carried out at a temperature of $42^{\circ} \mathrm{C}$ and $\mathrm{pH} 5.5$.

a half-life of 5 hours at $42^{\circ} \mathrm{C}$ (Table 8 ) and 2 hours at $50^{\circ} \mathrm{C}$ (Table 9). Temperature optimum of $40^{\circ} \mathrm{C}$ or higher for polygalacturonase stability has been reported in banana 
TABLE 11: Effect of substrates on activity of polygalacturonase from Mucor circinelloides.

\begin{tabular}{lcc}
\hline Substrate (0.1\%) & $\begin{array}{c}\text { Enzyme Activity } \\
(\mathrm{IU} / \mathrm{mL})\end{array}$ & $\begin{array}{c}\text { Relative Activity } \\
(\%)\end{array}$ \\
\hline PGA & 3.50 & 100.0 \\
Amylopectin & 0.21 & 6.0 \\
$\begin{array}{l}\text { Potato Dextrose Agar } \\
\text { Pectin Citrus }\end{array}$ & 0.12 & 3.7 \\
$\begin{array}{l}\text { (DE-85\%) } \\
\text { Pectin Apple } \\
\text { (methyl-7.8\%) }\end{array}$ & 0.38 & 11.0 \\
\hline
\end{tabular}

The experiment was carried out at a temperature of $42^{\circ} \mathrm{C}$ and $\mathrm{pH} 5.5$.

TABLE 12: Effect of thiols on activity of polygalacturonase from Mucor circinelloides.

\begin{tabular}{lcc}
\hline Thiols $(1 \mathrm{mM})$ & $\begin{array}{c}\text { Enzyme Activity } \\
(\mathrm{IU} / \mathrm{mL})\end{array}$ & $\begin{array}{c}\text { Relative Activity } \\
(\%)\end{array}$ \\
\hline L-Cystine & 3.80 & 108.57 \\
Ascorbic acid & 0.52 & 14.85 \\
B-Mercaptoethanol & 2.48 & 70.80 \\
Mercuric chloride & 0.48 & 13.71 \\
Sodium & 1.20 & 34.00 \\
metabisulphite & 3.50 & 100.00 \\
Control & &
\end{tabular}

TABLE 13: Effect of phenolics on activity of polygalacturonase from Mucor circinelloides.

\begin{tabular}{lcc}
\hline Phenolics (0.05 mM) & $\begin{array}{c}\text { Enzyme Activity } \\
(\mathrm{IU} / \mathrm{mL})\end{array}$ & $\begin{array}{c}\text { Relative Activity } \\
(\%)\end{array}$ \\
\hline Cinnamic Acid & 1.54 & 44.0 \\
Chlorogenic Acid & 2.05 & 58.0 \\
p-Coumaric Acid & 1.89 & 54.0 \\
Ferulic Acid & 1.96 & 56.0 \\
2,4-dinitrosalicylic & 1.79 & 51.1 \\
Acid & 3.51 & 100.0 \\
Control &
\end{tabular}

fruits and psychrophilic fungus Sclerotinia borealis [31, 32]. Polygalacturonase from $M$. flavus has been reported to be optimally active between $\mathrm{pH}$ range 3.5 to 5.5 and stable up to $40^{\circ} \mathrm{C}$ for 4 hours [33]. The optimum $\mathrm{pH}$ of 7.0 has been reported for polygalacturonase from Sporotrichum thermophile Apinis [34]. The $K_{m}$ and $V_{\max }$ values of polygalacturonase were found to be $2.2 \mathrm{mM}$ and $4.81 \mathrm{IU} / \mathrm{mL}$, respectively, at different concentrations of the substrate, that is, $0.1 \%$ to $0.5 \%(\mathrm{w} / \mathrm{v})$ by plotting the Line-Weaver Burke plot (Figure 3). Exo-polygalacturonase from Bacillus species KSMP 443 [35] and Penicillium frequentans [36] were found to have comparable $K_{m}$ values.

Polygalacturonase showed $5-15 \%$ decrease in enzyme activity in presence of $\mathrm{Mn}^{+2}, \mathrm{Co}^{+2}$, and $\mathrm{Mg}^{+2}$ whereas $\mathrm{Fe}^{+3}, \mathrm{Zn}^{+2}$ caused $27-31 \%$ decrease in the enzyme activity (Table 10). Thus, the enzyme did not require any metal ions to express its activity. Earlier, the effect of different

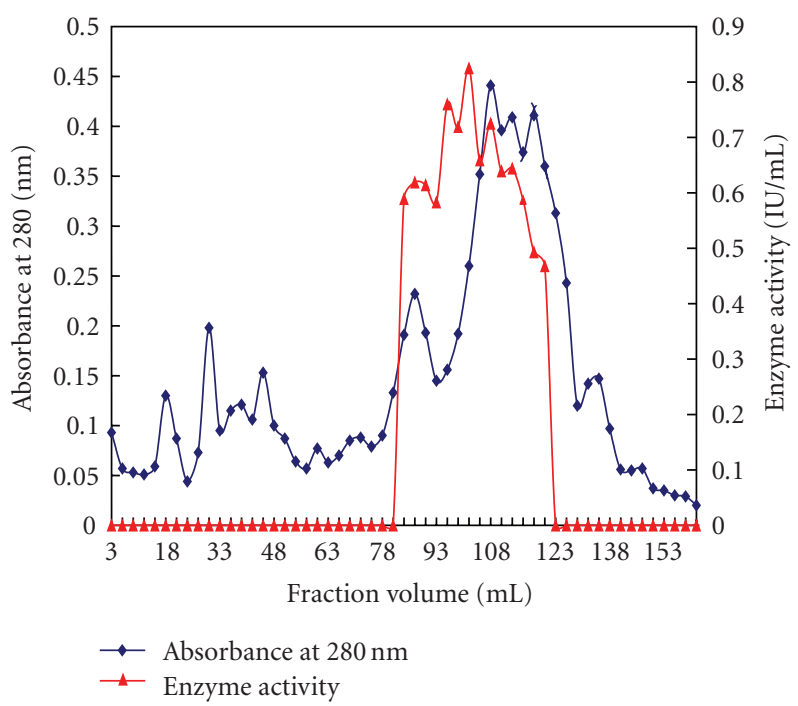

FIGURE 1: Elution profile of polygalacturonase on Sephacryl S-100 column.

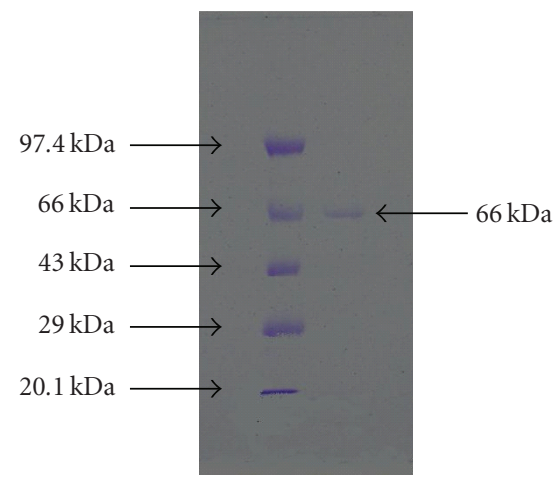

FIGURE 2: SDS-PAGE of purified polygalacturonase from Mucor circinelloides. Lane 1: Bangalore Genei Protein marker ( $\mathrm{kDa})$. Phosphorylase b 97.4. Bovine Serum Albumin 66.0. Ovalbumin 43.0. Carbonic anhydrase 29.0. Soybean Trypsin Inhibitor 20.1. Lane 2: Lyophilized concentrated fraction from Sephacryl S-100 Column.

metal cations at the concentration of $1 \mathrm{mM}$ on T. harzianum showed that all metal cations exhibited different and partial inhibitory effects on the activity of enzyme except $\mathrm{Mn}^{+2}$ and $\mathrm{Co}^{+2}$ which completely inhibited the enzyme activity [37]. Also, the addition of $0.01 \mathrm{mM} \mathrm{HgCl} 2$ increased the PG II activity of A. niger 3.4 times but did not affect PG I [38]. The purified polygalacturonase from $M$. circinelloides ITCC 6025 showed maximum activity with PGA $(0.1 \% \mathrm{w} / \mathrm{v})$, but it decreased with all other substrates indicating that PGA is the best substrate for maximum enzyme activity (Table 11). Polygalacturonase activity was progressively inhibited in the presence of thiols in comparison to that of control. Only L-cystine activated the reaction at $1 \mathrm{mM}$ concentration and showed enzyme activity $3.8 \mathrm{IU} / \mathrm{mL}$ in comparison to $3.5 \mathrm{IU} / \mathrm{mL}$ of control (Table 12). Mercuric chloride was the strongest inhibitor of enzyme at $1 \mathrm{mM}$ concentration followed by ascorbic acid. Phenolic acids, namely, cinnamic 


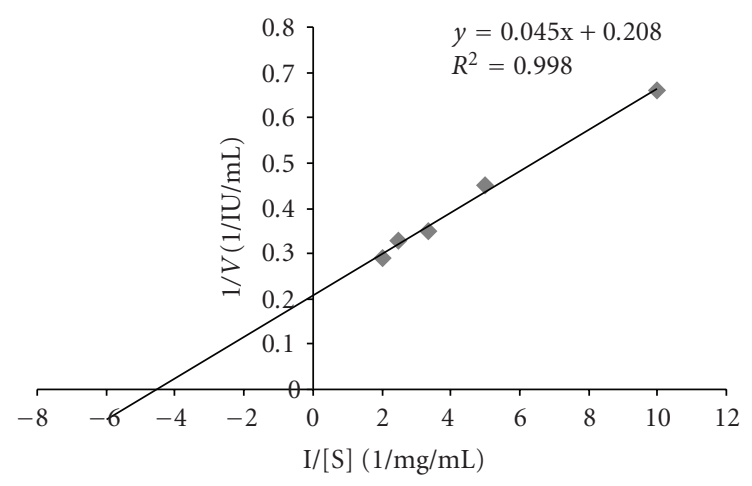

FIgURE 3: Line-weaver-Burke plot for polygalacturonase.

acid, chlorogenic acid, p-coumaric acid, ferulic acid, and 2,4-dinitro salicylic acid inhibited the enzyme activity. Cinnamic acid showed maximum inhibition of enzyme activity followed by 2,4-dinitrosalicyclic acid (Table 13). Previously, comparable results have been obtained for the effect of thiols and phenolics [39].

Thus, polygalacturonase from $M$. circinelloides ITCC 6025 can be exposed for its potential application such as juice clarification, textile, plant fiber processing, tea, coffee, oil extraction, and treatment of industrial waste water containing pectinaceous material. In the present investigation, although polygalacturonase from M. circinelloides ITCC 6025 has effectively been purified and characterized, the enzyme properties may, however, be further improved via efficient immobilization onto a suitable matrix. The immobilized enzyme can be of industrial advantage in terms of sturdiness, availability, inertness, low price, reusability, and temperature stability [40].

\section{Funding}

The financial support from Department of Biotechnology, Ministry of Science and Technology, Government of India, to Department of Biotechnology, Himachal Pradesh University, Shimla (India), is thankfully acknowledged.

\section{Acknowledgment}

The authors are also thankful to Bioinformatics Centre (SubDIC), Himachal Pradesh University, Shimla (India) for webbased resource support.

\section{References}

[1] F. M. Rombouts and W. Pilnik, "Pectic enzymes," in Economic Microbiology, Microbial Enzymes and Bioconversions, A. H. Rose, Ed., pp. 227-282, Academic Press, London, UK, 1980.

[2] E. F. Torres, T. V. Sepulveda, and G. V. Gonzalez, "Production of hydrolytic depolymerising pectinases," Food Technology and Biotechnology, vol. 44, no. 2, pp. 221-227, 2006.

[3] L. Parenicova, J. A. E. Benen, H. C. M. Kester, and J. Visser, "Studies on polygalacturonase of certain yeasts," Biochemical Journal, vol. 259, pp. 577-585, 2000.
[4] D. R. Kashyap, P. K. Vohra, S. Chopra, and R. Tewari, "Applications of pectinases in the commercial sector: a review," Bioresource Technology, vol. 77, no. 3, pp. 215-227, 2001.

[5] P. Kotzekidov, "Production of polygalacturonases by Byssachlamys fulva," Journal of Industrial Microbiology, vol. 7, pp. 53$56,1991$.

[6] Q. K. Beg, M. Kapoor, R. P. Tiwari, and G. S. Hoondal, "Bleach-boosting of eucalyptus kraft pulp using combination of xylanase and pectinase from Streptomyces sp. QG-11-3," Research Bulletin of the Panjab University, vol. 57, pp. 71-78, 2001.

[7] M. C. Baracat, M. C. Vanetti, E. F. Araujo, and D. O. Silva, "Growth conditions of a pectinolytic Aspergillus fumigatus for degumming of natural fibres," Biotechnology Letters, vol. 13, no. 10, pp. 693-696, 1991.

[8] J. D. Evans, D. E. Akin, and J. A. Foulk, "Flax-retting by polygalacturonase-containing enzyme mixtures and effects on fiber properties," Journal of Biotechnology, vol. 97, no. 3, pp. 223-231, 2002.

[9] T. Sakai, "Degradation of pectins," in Phytochemistry, G. Winkelmann, Ed., pp. 57-81, VCH, Weinheim, Germany, 1992.

[10] F. Bruhlmann, M. Leupin, K. H. Erismann, and A. Fiechter, "Enzymatic degumming of ramie bast fibers," Journal of Biotechnology, vol. 76, no. 1, pp. 43-50, 2000.

[11] J. Fiedurek, J. Szczodrak, and J. Rogalski, "Seeds as natural matrices for immobilization of Aspergillus niger mycelium producing pectinases," Journal of Applied Bacteriology, vol. 78, no. 4, pp. 409-412, 1995.

[12] F. I. Ustok, T. Canan, and N. Gogus, "Solid-state production of polygalacturonase by Aspergillus sojae ATCC 20235," Journal of Biotechnology, vol. 127, no. 2, pp. 322-334, 2007.

[13] D. Dinu, T. N. Marina, S. Gheorghe, C. Marieta, and D. Anca, "Enzymes with new biochemical properties in the pectinolytic complex produced by Aspergillus niger MIUG 16," Journal of Biotechnology, vol. 131, no. 2, pp. 128-137, 2007.

[14] C. Lang and H. Dörnenburg, "Perspectives in the biological function and the technological application of polygalacturonases," Applied Microbiology and Biotechnology, vol. 53, no. 4, pp. 366-375, 2000.

[15] T. Canan, N. Dogan, and N. Gogus, "Biochemical and thermal characterization of crude exo-polygalacturonase produced by Aspergillus sojae," Food Chemistry, vol. 111, no. 4, pp. 824-829, 2008.

[16] W. M. Jurick, I. Vico, J. L. Mcevoy, B. D. Whitaker, W. Janisiewicz, and W. S. Conway, "Isolation, purification, and characterization of a polygalacturonase produced in Penicillium solitum-decayed 'Golden Delicious' apple fruit," Phytopathology, vol. 99, no. 6, pp. 636-641, 2009.

[17] M. Smogyi, "Notes on sugar determination," The Journal of Biological Chemistry, vol. 195, no. 1, pp. 19-23, 1952.

[18] O. H. Lowry, N. J. Rosebrough, A. L. Farr, and R. J. Randall, "Protein measurement with Folin phenol reagent," The Journal of Biological Chemistry, vol. 193, pp. 265-275, 1951.

[19] U. K. Laemmli, "Cleavage of structural proteins during the assembly of the head of bacteriophage T4," Nature, vol. 227, no. 5259, pp. 680-685, 1970.

[20] U. Phutela, V. Dhuna, S. Sandhu, and B. S. Chadha, "Pectinase and polygalacturonase production by a thermophilic Aspergillus fumigatus isolated from decomposting orange peels," Brazilian Journal of Microbiology, vol. 36, no. 1, pp. 6369, 2005.

[21] M. Kapoor, Q. Khalil Beg, B. Bhushan, K. S. Dadhich, and G. S. Hoondal, "Production and partial purification and 
characterization of a thermo-alkali stable polygalacturonase from Bacillus sp. MG-cp-2," Process Biochemistry, vol. 36, no. 5, pp. 467-473, 2000.

[22] G. Aguilar and C. Huitron, "Constitutive exo-pectin produced by Aspergillus sp. CH-Y-1043 on different carbon source," Biotechnology Letters, vol. 12, no. 9, pp. 655-660, 1990.

[23] D. R. Kashyap, S. K. Soni, and R. Tewari, "Enhanced production of pectinase by Bacillus sp. DT7 using solid state fermentation," Bioresource Technology, vol. 88, no. 3, pp. 251254, 2003.

[24] N. H. C. Pattat, G. Condemine, W. Nasser, and S. Reverchon, "Regulation of pectinolysis in Erwinia chrysanthemi," Annual Review of Microbiology, vol. 50, pp. 213-257, 1996.

[25] E. S. Martins, D. Silva, R. S. R. Leite, and E. Gomes, "Purification and characterization of polygalacturonase produced by thermophilic Thermoascus aurantiacus CBMAI-756 in submerged fermentation," World Journal of Microbiology and Biotechnology, vol. 127, pp. 322-334, 2007.

[26] S. M. C. Celestino, S. Maria de Freitas, F. J. Medrano, M. V. D. Sousa, and E. X. F. Filho, "Purification and characterization of a novel pectinase from Acrophialophora nainiana with emphasis on its physicochemical properties," Journal of Biotechnology, vol. 123, no. 1, pp. 33-42, 2006.

[27] J. C. Esquivel and C. E. Voget, "Purification and partial characterization of an acidic polygalacturonase from Aspergillus kawachii," Journal of Biotechnology, vol. 110, no. 1, pp. 21-28, 2004.

[28] M. B. B'ene'dicte, Robert Létoublon, and M. Fèvre, "Purification and characterization of two endopolygalacturonases secreted during the early stages of the saprophytic growth of Sclerotinia sclerotiorum," FEMS Microbiology Letters, vol. 158, no. 1, pp. 133-138, 1998.

[29] H. Urbanek and J. Z. Sobczak, "Polygalacturonase of Botrytis cinerea E-200 Pers," Biochimica et Biophysica Acta, vol. 377, no. 2, pp. 402-409, 1975.

[30] J. Zhang, B. D. Bruton, and C. L. Biles, "Purification and characterization of a prominent PGase isoenzyme produced by Phomopsis cucurbitae in decayed muskmelon fruit," Mycological Research, vol. 103, pp. 21-27, 1999.

[31] N. Pathak, S. Mishra, and G. G. Sanwal, "Purification and characterization of polygalacturonase from banana fruit," Phytochemistry, vol. 54, no. 2, pp. 147-152, 2000.

[32] T. Takasawa, K. Sagisaka, K. Yogi, et al., "Polygalacturonase isolated from the culture of the psychrophilic fungus Sclerotinia borealis," Canadian Journal of Microbiology, vol. 43, no. 5, pp. 417-424, 1997.

[33] R. V. Gadre, G. V. Driessche, J. V. Beeumen, and M. K. Bhat, "Purification, characterization and mode of action of an endopolygalacturonase from the psychophilic fungus Mucor flavus," Enzyme and Microbial Technology, vol. 32, pp. 321-330, 2003.

[34] G. Kaur, S. Kumar, and T. Satyanarayana, "Production, characterization and application of a thermostable polygalacturonase of a thermophilic mould Sporotrichum thermophile Apinis," Bioresource Technology, vol. 94, no. 3, pp. 239-243, 2004.

[35] T. Kobayashi, N. Higaki, N. Yajima, et al., "Purification and properties of a galacturonic acid-releasing exopolygalacturonase from a strain of Bacillus," Bioscience, Biotechnology and Biochemistry, vol. 65, no. 4, pp. 842-847, 2001.

[36] R. I. Barense, M. A. D. S. C. Chellegatti, M. J. V. Fonseca, and S. Said, "Partial purification and characterization of exopolygalacturonase II and III of Penicillium frequentans," Brazilian Journal of Microbiology, vol. 32, no. 4, pp. 327-330, 2001.
[37] S. A. Mohamed, T. M. I. E. Christensen, and J. D. Mikkelsen, "New polygalacturonases from Trichoderma reesei: characterization and their specificities to partially methylated and acetylated pectins," Carbohydrate Research, vol. 338, no. 6, pp. 515-524, 2003.

[38] T. Sakamoto, E. Bonnin, B. Quemener, and J. F. Thibault, "Purification and characterisation of two exopolygalacturonases from Aspergillus niger able to degrade xylogalacturonan and acetylated homogalacturonan," Biochimica et Biophysica Acta, vol. 1572, no. 1, pp. 10-18, 2002.

[39] A. Payasi, P. C. Misra, and G. G. Sanwal, "Purification and characterization of pectate lyase from banana (Musa acuminata) fruits," Phytochemistry, vol. 67, no. 9, pp. 861-869, 2006.

[40] S. Saxena, S. Shukla, A. Thakur, and R. Gupta, "Immobilization of polygalacturonase from Aspergillus niger onto activated polyethylene and its application in apple juice clarification," Acta Microbiologica et Immunologica Hungarica, vol. 55, no. 1, pp. 33-51, 2008. 

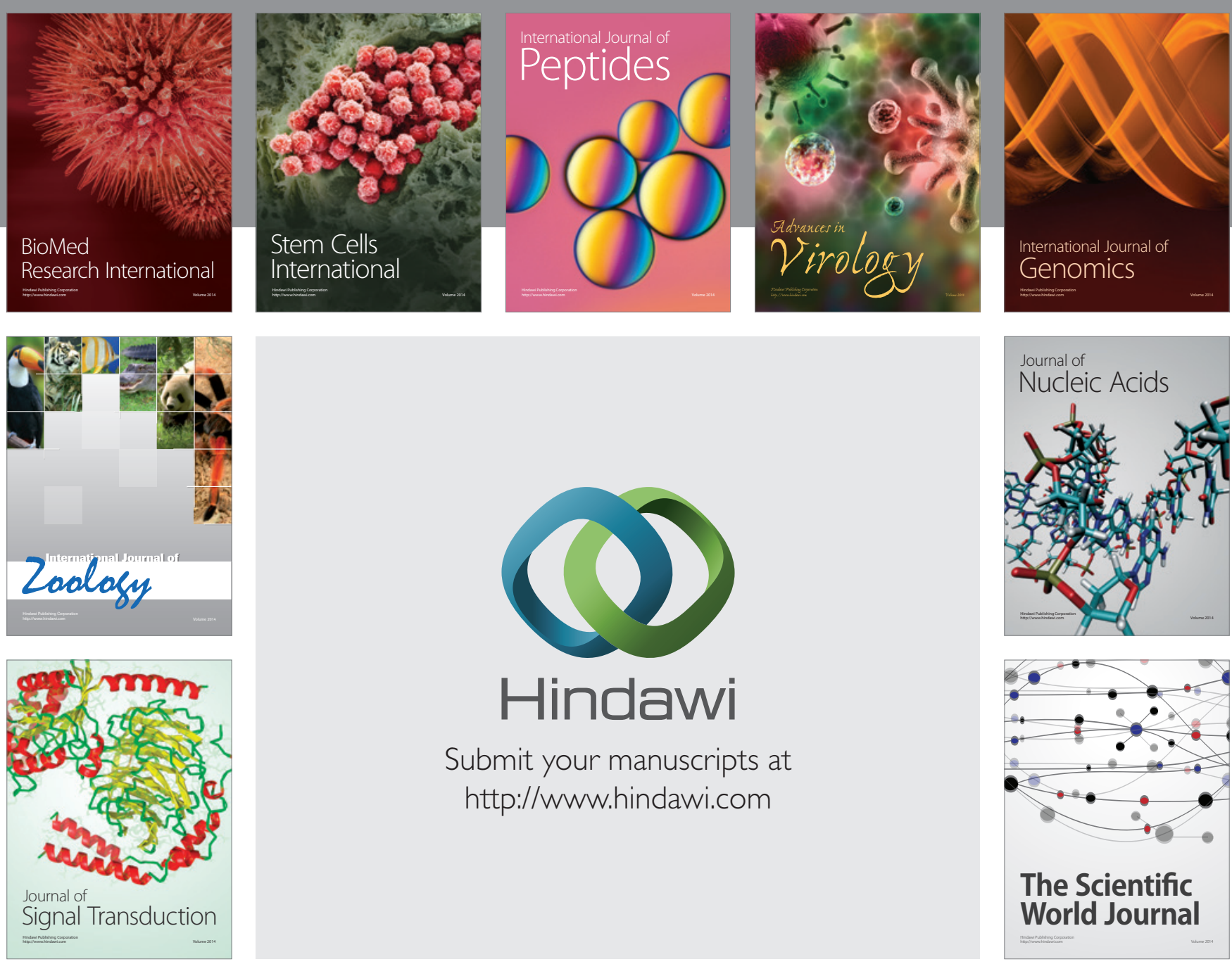

Submit your manuscripts at

http://www.hindawi.com
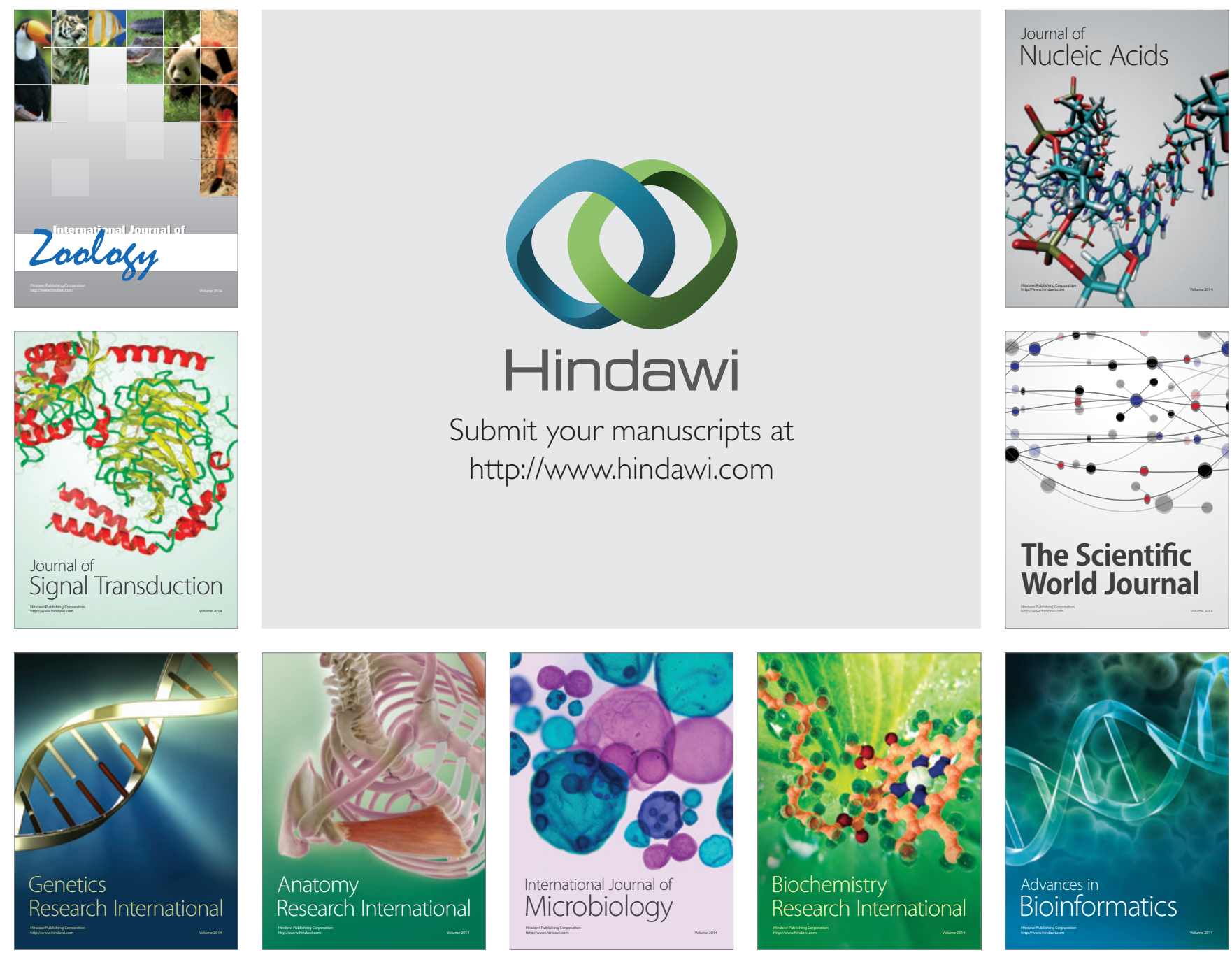

The Scientific World Journal
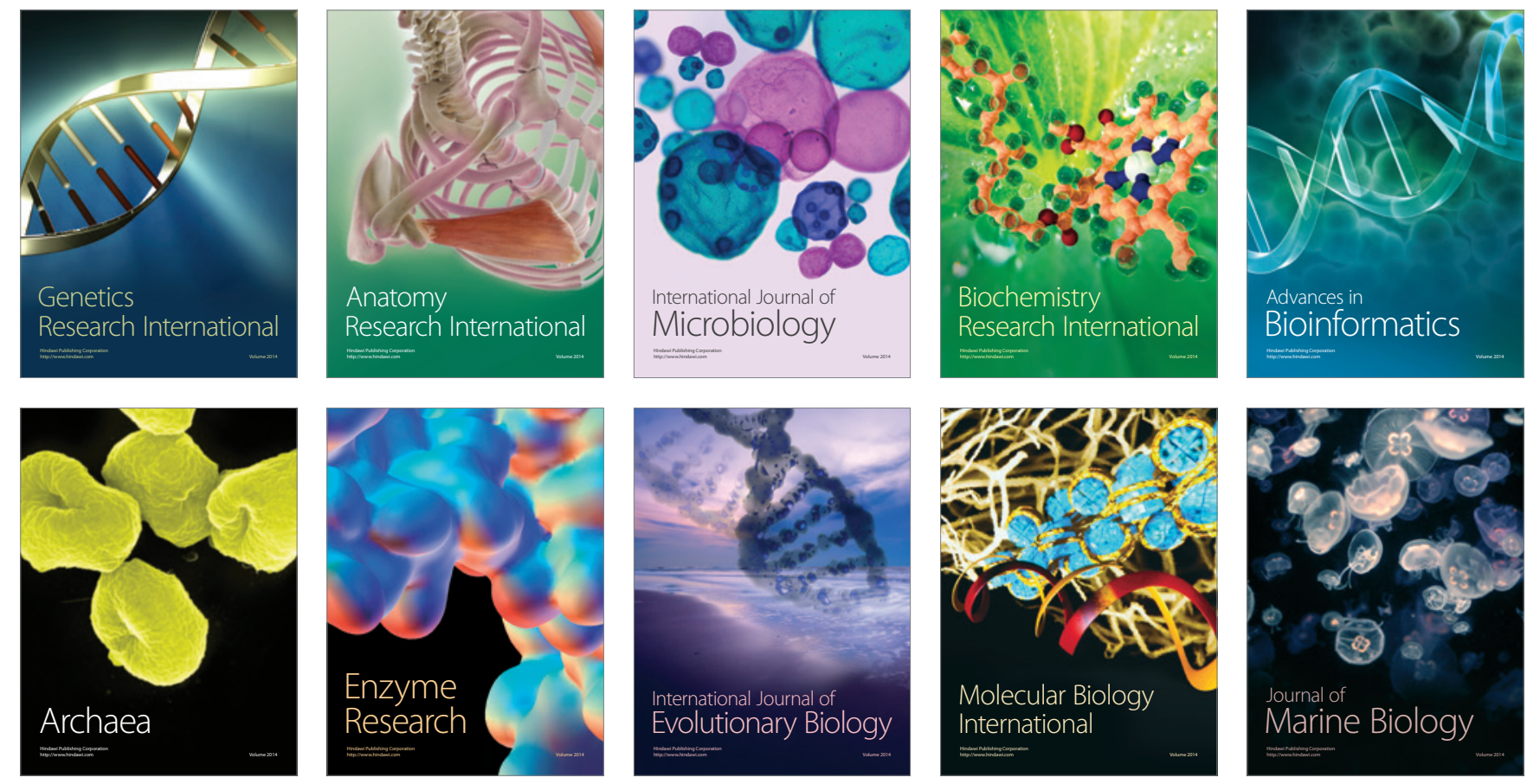